\title{
MENINGKATKAN KETERAMPILAN LEMPAR-TANGKAP \\ BOLA KECIL MELALUI MODIFIKASI PERMAINAN TRADISIONAL BOY-BOYAN PADA SISWA KELAS V SDN CISITU 2 KOTA BANDUNG
}

\author{
Muhamad Irfa Septanto, Nuryadi, Luqmannul Haqim Lubay \\ (FPOK Universitas Pendidikan Indonesia)
}

irfaseptanto@gmail.com

\begin{abstract}
Abstrak
Penelitian ini bertujuan untuk meneliti tingkat keterampilan lempar-tangkap, dilaksanakan dengan metode penelitian tindakan kelas yang terdiri atas tahapan perencanaan tindakan, pelaksanaan tindakan, observasi dan refleksi. Penelitian dilaksanakan terhadap 34 Siswa kelas V SDN Cisitu 2 Kota Bandung. Proses penelitian dibagi menjadi dua siklus yang terdiri atas empat tindakan. yang dikemas dalam bentuk permainan yang berlevel dan bertahap dari yang termudah sampai yang tersulit. Data dikumpulkan dengan menggunakan instrumen GPAI. Berdasarkan hasil analisis data, didapat kesimpulan melalui penerapan modifikasi permainan tradisional boy-boyan dapat meningkatkan keterampilan lempar-tangkap. Sebagai saran dari hasil penelitian, dalam pemberian materi pembelajaran bola kecil, hendaknya diberikan secara bertahap dari yang termudah sampai yang tersulit, penyampaian materi pembelajaran permainan bola kecil khususnya permainan lempartangkap, dapat menggunakan tugas gerak yang dititik beratkan pada pengembangan gerak manipulatif. Sehingga keterampilan lempar-tangkap dapat ditingkatkan, untuk mendapatkan hasil yang lebih baik, perlu dilanjutkan dengan siklus berikutnya, sampai mencapai hasil yang optimal dan dapat dilakukan penelitian yang membandingkan keterampilan permainan lempar-tangkap siswa laki-laki dan siswa perempuan dengan menerapkan modifikasi permainan.

Kata kunci: Keterampilan Lempar-Tangkap Bola Kecil, Modifikasi Permainan Tradisional BoyBoyan
\end{abstract}

\section{PENDAHULUAN}

Pendidikan jasmani pada hakikatnya adalah peroses pendidikan yang memanfaatkan aktivitas fisik untuk menghasilkan perubahan holistic dalam kualitas individu, baik dalam fisik, mental, serta emosional. Pendidikan jasmani memperlakukan anak sebagai sebuah kesatuan utuh, mahluk social, dari pada hanya menganggapnya sebagai seseorang yang terpisah kualitas fisik dan mentalnya. Mahendra(2009, Hlm 3).
Program pembelajaran pendidikan jasmani memiliki tujuan dan fungsi untuk menumbuh kembangkan seluruh domain yang dimiliki oleh setiap siswa. Sedangkan pada aspek afektif, program pendidikan jasmani menitik beratkan kepada pembentukan sikap untuk membentuk kepribadian yang baik yang sesuai dengan norma dan etika di masyarakat.

Di dalam pembelajaran gerak, anak tidak hanya di tuntut untuk bisa melakukan tugas gerak dengan baik, melainkan anak harus terampil dalam melakukan tugas gerak dan konsep bermain yang di berikan oleh guru. 
Dengan bermain, dan melalui permainan anak dapat memiliki pengalaman sukses dan prestasi atau mengalami kekalahan. Disamping itu, beberapa tujuan lain dapat dicapai melalui permainan, seperti menerima aturan dan pemahaman yang baik pada dirinya dalam situasi kompetitif dan kooperatif. Permainan tidak secara melekat suatu kesenangan. Permainan harus diajarkan dalam suasana yang membuat anak percaya bahwa dengan partisipasi penuh anak sangat diperlukan dalam permainan tersebut. Jika anak tersisih karena keterampilannya jelek, maka permainan akan menjadi suatu pengalaman yang tidak menyenangkan. Dari uraian di atas peneliti mencoba menerapkan pendekatan bermain melalui permainan tradisional boy-boyan yang di modifikasi, hal ini bertujuan untuk menghindari pembelajaran yang menjenuhkan dan untuk menumbuhkan rasa antusiasme pada siswa, melalui penerapan permainan ini juga dapat mengaplikasikan gerak lempar-tangkap melalui situasi bermain. Tidak menutup kemungkinan keterampilan gerak dasar yang buruk atau rendah mengakibatkan permainan kurang menarik. Untuk itu seorang guru harus mampu mengatasinya. Adapun Makna Bermain dalam Pendidikan menurut Sukintaka (1992, hlm. 7) bahwa:

1). Bermain merupakan aktivitas yang dilakukan dengan suka rela atas dasar rasa senang. 2). bermain dengan rasa senang, menumbuhkan aktivitas yang dilakukan secara spontan. 3). bermain dengan rasa senang, untuk memperoleh kesenangan, menimbulkan kesadaran agar bermain dengan baik perlu berlatih, kadang-kadang memerlukan kerjasama dengan teman, menghormati lawan, mengetahui kemampuan teman, patuh pada peraturan, dan mengetahui kemampuan dirinya sendiri.

Jadi melalui pendekatan bermain dalam pembelajaran gerak, keterampilan yang buruk atau rendah dapat diperbaiki, sehingga dengan meningkatnya keterampilan gerak dasar penerimaan pembelajaran pun akan mudah diserap. Dengan demikian diharapkan kemampuan gerak siswa dapat meningkat dan tujuan-tujuan pembelajaran pun dapat tercapai

Menurut penjelasan itu jelas melalui permainan tradisional dalam pembelajaran gerak untuk mencapai keterampilan sangat mungkin diperoleh. Sementara dalam klasifikasi yang lebih umum penelitian yang akan digunakan oleh peneliti adalah permainan tradisional boy-boyan karena permainan ini mengandung unsur melempar dan menangkap

Permainan boy-boyan sendiri adalah salah satu jenis permainan bola kecil yang mengutamakan beberapa unsur kekompakan, ketangkasan dan kegembiraan. Permainan ini biasa dilakukan di lapangan terbuka. Pada anakanak usia sekolah dasar, permainan ini bisa melatih kedisiplinan diri serta memupuk rasa kebersamaan dan solidaritas antar teman. Agar dapat bermain boy-boyan dengan baik kita dituntut memiliki beberapa keterampilan yaitu melempar dan menangkap bola serta kemampuan memahami konsep bermain. Menurut E.R. Guthrie (dalam Schmitd : 1991) yang dikutip oleh Mahendra, Ma,mun (1998, hlm. 131-132), dalam Modul Teori Pembelajaran Gerak Dan Motorik menyatakan keterampilan adalah: "keterampilan merupakan kemampuan untuk membuat hasil akhir yang maksimum dan pengeluaran energi dan waktu yang minimum." Sedangkan menurut (Singer ; 1980) yang dikutip oleh Mahendra, Ma'mun (1998, hlm. 132) menyatakan bahwa: "keterampilan adalah derajat keberhasilan yang konsisten dalam mencapai suatu tujuan dengan efisien dan efektif'. Kedua definisi diatas, walaupun dinyatakan secara berbeda namun sama-sama memiliki unsur pokok yang menjadi ciri dari batasan keterampilan. Salah satu unsur pokok yang berhubungan dengan gerak keterampilan lempar-tangkap menurut Mahendra, Ma'mun (1998, hlm. 132) bahwa:

Keterampilan mengandung arti pelaksanaan yang cepat, dalam arti penyelesaian tugas gerak itu dalam waktu yang minimim. Semakin cepat pelaksanaan suatu gerak, tanpa mengorbankan hasil akhir (kualitas) yang diharapkan, maka akan membuat terakuinya keterampilan orang yang bersangkutan". Jadi untuk mencapai tujuan pembelajaran yang di inginkan untuk meningkatkan keterampilan di butuhkan berbagai unsur yang mendukung untuk tercapainya hasil pembelajaran gerak yang di inginkan.

Berdasarkan uraian latar belakang di atas, peneliti tertarik untuk melakukan penelitian tindakan kelas dengan judul "Upaya meningkatkan keterampilan lempar tangkap melalui modifikasi permainan tradisional boyboyan pada siswa kelas V SDN Cisitu 2 Kota Bandung." 


\section{METODE}

Metode yang digunakan dalam penelitian adalah Class Room Action Research, sebab penelitian dimaksudkan untuk mengetahui pengaruh sebab akibat suatu variabel terhadap variabel lain, yaitu penerapan modifikasi permainan tradisional untuk meningkatkan keterampilan lempar-tangkap bola kecil siswa.

Populasi dalam penelitian ini adalah siswa kelas V SDN Cisitu 2 Kota Bandung. Sedangkan sampel penelitian dipilih 43 orang siswa lakilaki 20 dan siswa perempuan 23 di Sekolah Dasar Negeri Cisitu 2 Kota Bandung.

Desain penelitian yang dipilih oleh penulis adalah desain Kurt Lewin 2 siklus dan 4 tindakan mulai dari merancang perencanaan, melaksanakan tindakan, observasi dan merefleksi hasil tindakan yang telah diberikan. Sebelum melakukan proses penelitian, terlebih dahulu melakukan observasi awal untuk meyakikankan permasalahan benar-benar merupakan suatu masalah untuk dijadikan bahan penelitian.

Instrumen atau alat yang digunakan untuk mengumpulkan data dalam penelitian ini adalah Game Performance Assisment Instrumen (GPAI), alat ukur ini mengambil 4 komponen penilaian yang di ambil dari 7 komponen GPAI yang telah disesuaikan dengan bentuk dan karakteristik permainan yang diberikan, keempat komponen tersebut yaitu: 1. Keputusan yang diambil (Decision Marking) yaitu pemain melakukan lempar-tangkap dengan teman sekelompok dengan tujuan untuk mematikan pergerakan lawan. 2. Melaksanakan keterampilan (Skill Execution) yaitu pemain melakukan gerakan lempar-tangkap bola dalam permainan. 3). Memberi dukungan (Support) yaitu dalam permainan, pemain membantu teman sekelompok yang lebih menguntungkan untuk mencetak skor. 4). Perlindungan (Base) yaitu pemain berusaha melindungi tumpukan genting dalam permainan boy-boyan dari lawan yang berusaha menyusun.

\section{HASIL DAN PEMBAHASAN}

Berdasarkan hasil penelitian dari mulai observasi awal sampai dengan siklus dua tindakan dua, diketahui bahwa penerapan modifikasi permainan tradisional boy-boyan telah meningkatkan keterampilan lempartangkap bola pada siswa kelas V SDN Cisitu 2 Kota Bandung. Adapun data dan rangkuman hasil akhir penelitian dari observasi awal sampai dengan siklus dua tindakan dua dapat digambarkan dalam beberapa bentuk sebagai berikut ini: 
Tabel 4.6

Perolehan Nilai Persentase Keterampilan Lempar - Tangkap

Dari Setiap Tindakan

\begin{tabular}{|l|l|l|}
\hline $\begin{array}{l}\text { Kegiatan yang } \\
\text { dilakukan }\end{array}$ & $\begin{array}{l}\text { Rata-rata penilaian hasil } \\
\text { keterampilan lempar - } \\
\text { tangkap }\end{array}$ & Keterangan \\
\hline Pra Observasi & & Belum Tuntas \\
\hline Siklus 1 Tindakan 1 & & Belum Tuntas \\
\hline Siklus 1 Tindakan 2 & & Belum Tuntas \\
\hline Siklus 2 Tindakan 1 & & Belum Tuntas \\
\hline Siklus 1 Tindakan 2 & & Tuntas \\
\hline
\end{tabular}

Grafik 4.1

Grafik Perolehan Nilai Persentase Keterampilan Lempar-Tangkap Dari Setiap Tindakan

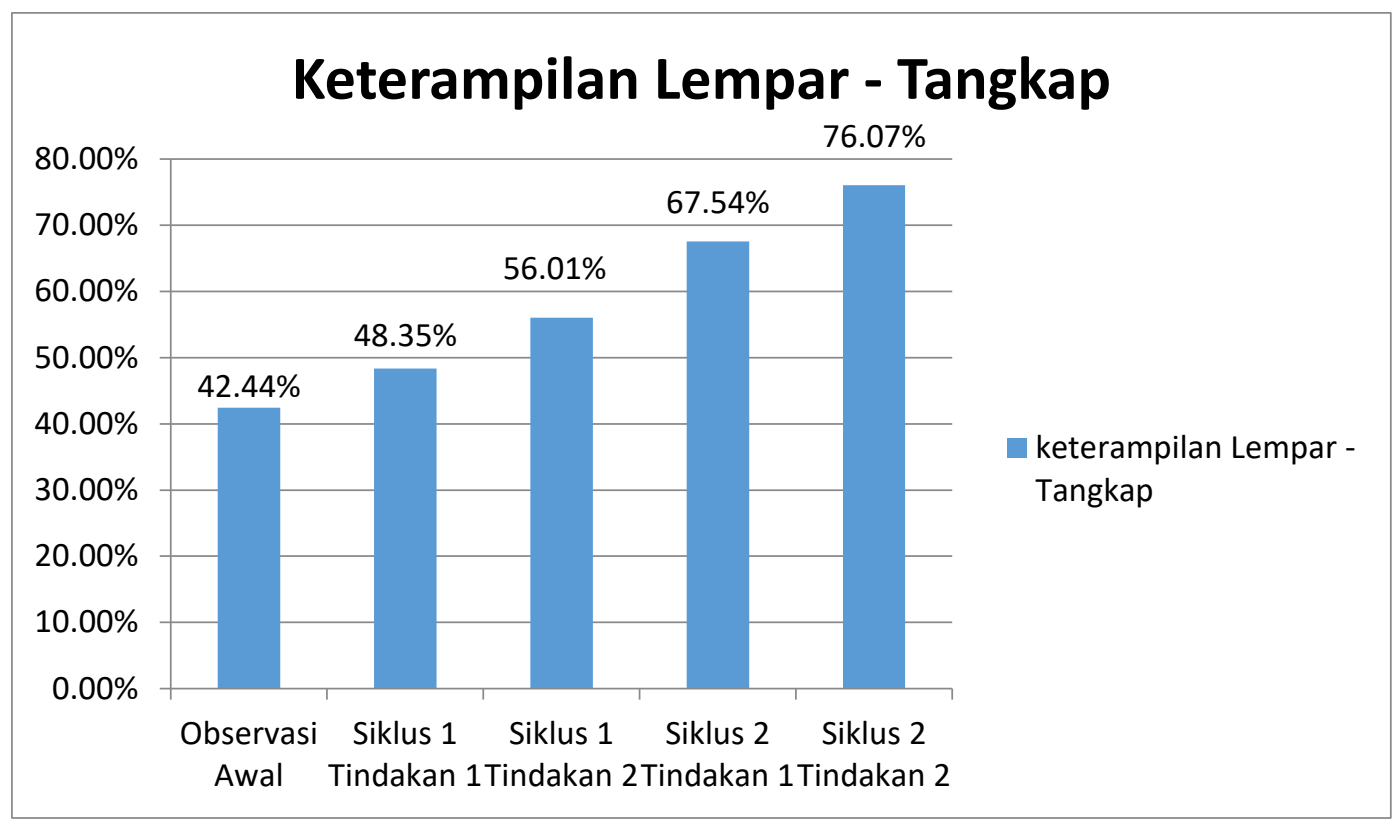




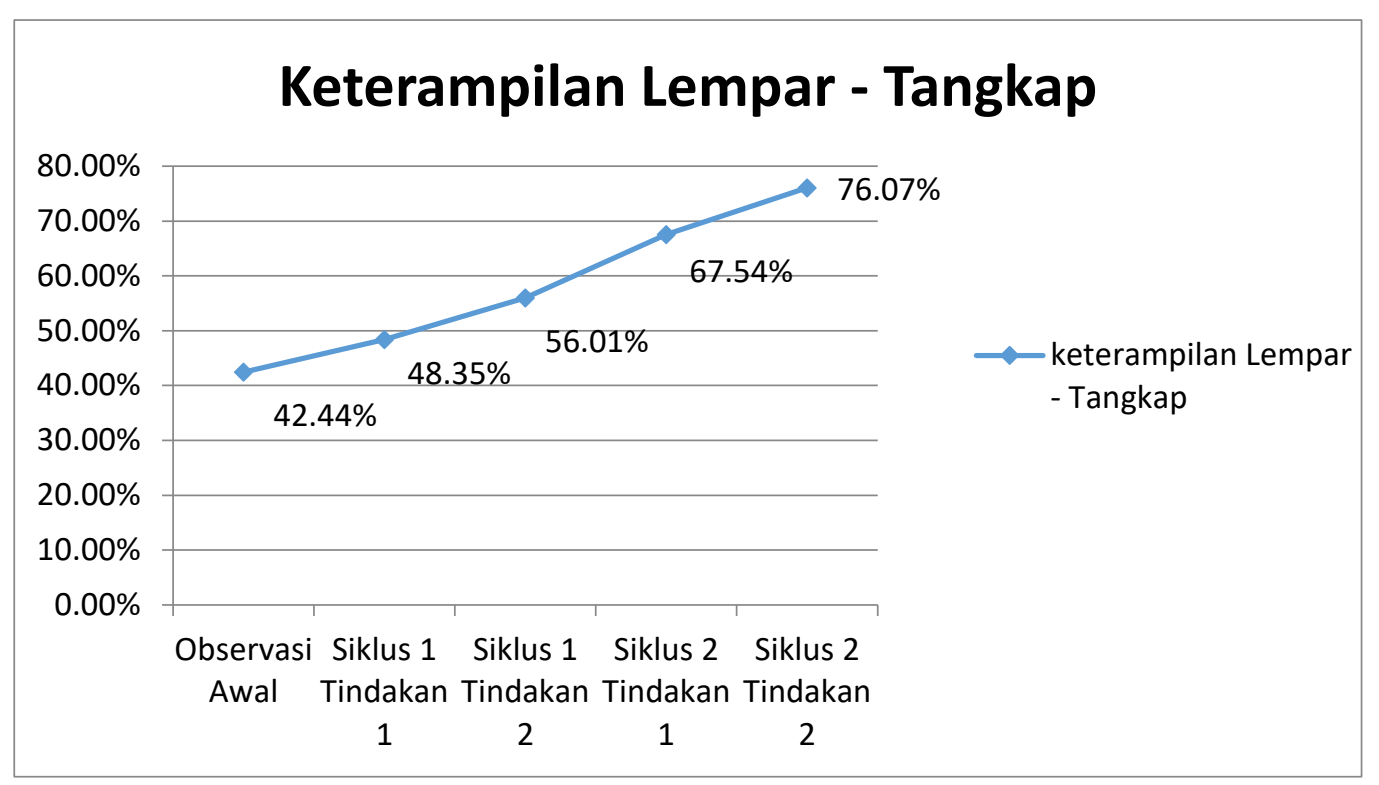

Pembelajaran gerak merupakan salah satu tujuan utama mengapa pendidikan jasmani diterapkan di sekolah. Dari sebuah pembelajaran sudah barang tentu yang diinginkan adalah hasil. Hasil dalam pembelajaran gerak dapat disebut dengan gerak keterampilan, Mahendra (1998 hlm. 132) : "Jika setiap tujuan pembelajaran gerak harus berakhir dengan suatu hasil maka tidak lain hasil itu adalah keterampilan gerak."

Dalam mata pelajaran pendidikan jasmani di sekolah dasar bukan suatu yang asing apabila seorang guru penjas memberikan permainan kepada siswa yang di dalamnya mencakup beberapa keterampilan. Secara tidak langsung melalui permainan yang telah dirancang sedemekian menarik, itu merupakan cara yang dapat mencapai hasil akhir yang di inginkan. Permainan yang diberikanpun tidak sembarang permainan tetapi harus mencakup ranah kognitif, afektif dan psikomotor siswa.

Seorang guru dituntut untuk selalu bisa menciptakan suasana permainan yang menyenangkan, bila perlu memodifikasi permainan yang sudah ada supaya lebih menarik lagi dan tidak memebosankan. Hal ini berguna untuk menhindari kejenuhan pada siswa. Lutan dalam 1998 dalam

(dalamhttp://www.academia.edu/7663298/M odifikasi_Pembelajaran_penjasorkes Berbasis PAIKEM Pada Standar_Proses).
"Modifikasi dalam mata pelajaran pendidikan jasmani diperlukan, dengan tujuan agar : a) Siswa memperoleh kepuasan dalam mengikuti pelajaran, b) Meningkatkan kemungkinan keberhasilan dalam berpartisipasi, c) Siswa dapat melakukan pola gerak secara benar".

Maksud dari modifikasi disini ialah penyampaian keterampilan berolahraga dengan mengubah keterampilan permainan tradisional ke dalam bentuk keterampilan yang sesuai dengan kemampuan anak. Ini bertujuan agar anak atau siswa lebih termotivasi dan memperoleh kepuasan dalam melaksanakan setiap tugas gerak yang diinstruksikan oleh guru, yang terjadi dilapangan dengan diterapkannya modifikasi permainan tradisional boy-boyan seluruh siswa terlihat lebih antusias melakukan tugas gerak yang diinstruksikan oleh guru.

Permainan yang diterapkan dalam penelitian ini adalah melalui modifikasi permainan tradisional boy-boyan yang dapat dijadikan sebagai media untuk memberikan pendidikan baik jasmani maupun rohani. Misalnya menumbuhkan sifat disiplin, sosial, kejujuran, kemandirian dan keterampilan. Permainan yang dilakukan secara beregu dapat memupuk kerjasama dikarenakan adanya aturan permainan, anak-anak dapat menentukan pihak yang kalah dan menang. Kondisi ini menuntut 
anak untuk bersikap disiplin guna mencapai sebuah kemenangan. Permainan tradisional menghendaki para pelaku untuk berkomunikasi dan bertemu, para pelaku akan termotivasi untuk untuk termotivasi untuk mempelajari banyak hal sehingga dapat menumbuhkan rasa percaya diri. Melalui permainan tradisional yang terprogram dan menyenangkan, anak secara tidak sadar akan dituntut berpikir dan mengingat serta mengambil keputusan dengan cerdas untuk mempertahankan timnya dari kekalahan.

\section{KESIMPULAN}

Dari hasil penelitian yang telah dilaksanakan oleh peneliti dari mulai observasi awal sampai dengan tindakan terakhir, yaitu siklus 2 tindakan 2, dapat diketahui bahwa keterampilan lempartangkap bola pada siswa kelas V SDN Cisitu 2 Kota Bandung telah meningkat, dari Observasi
Bekerja sama, saling menghormati lawan juga dapat dikembangkan pada siswa apabila guru mampu memberikan pembelajaran permainan sesuai standar kompetensi dan kompetensi dasarnya. Jadi melalui pembelajaran permainan yang menyenangkan dan terprogram di sekolah dapat menumbuh kembangkan aspek jasmani, psikis dan sosial yang diperlukan dalam perkembangan seorang anak. Pembentukan karakter atau gerak dapat terjadi di lingkungan sekolah maupun masyarakat melalui permainan.

awal $42,44 \%$ menjadi $76,01 \%$ peneliti menyimpulkan bahwa dengan melalui penerapan modifikasi permainan tradisional boy-boyan dapat meningkatkan keterampilan lempar-tangkap bola siswa. 


\section{DAFTAR PUSTAKA}

Abduljabar, B. (2009). Manajemen Pendidikan jasmani dan Olahraga. Bandung: FPOK UPI.

Abduljabar, B. (2010). Statistika Dalam Penjas. Bandung: FPOK UPI.

Abduljabar, B. (2011). Pedagogi Olahraga. Bandung: FPOK UPI.

Arikunto, S. (2009). Penelitian Tindakan Kelas. Jakarta : PT Bumi Aksara.

Budiman \& Hidayat. (2011) Psikologi Anak dalam Pendidikan Jasmani. Bandung: FPOK UPI.

Hidayat, Y. (2009). Pengantar Psikologi Olahraga. Bandung: CV Bintang Warli Artika.

Hidayat, Y (2011), Pedoman Penulisan Penelitian Tindakan Kelas Dalam pendidikan Jasmani, Olahraga, dan kesehatan. Bandung: FPOK-UPI.

Khamdani, A (2010). Olahraga Tradisional Indonesia, Aceh: PT Maraga Borneo Tarigas.

Kunandar. (2012). Langkah Mudah Penelitian Tindakan Kelas Sebagai Pengembangan Profesi guru. Jakarta: PT Raja grafindo Persada.

Mahendra, A. (1998). Teori Pembelajaran Gerak dan Motorik. Bandung: IKIP BANDUNG. Mahendra, A. (2009), Asas dan Falsafah Pendidikan Jasmani. Bandung: FPOK-UPI.

Saputra, Y. (2010), Perkembangan dan Belajar Motorik. Bandung: FPOK-UPI.

Sugiyono. (2013). Metode Penelitian Pendidikan Pendekatan Kuantitatif, Kualitatif, dan R\&D. Bandung: Alfabeta.

Sukintaka, (1992). Teori Bermain . Jakarta: Departemen Pendidikan Dan Kebudayaan Direktorat Jenderal Pendidikan Tinggi Proyek Pembinaan Tenaga Kerja Pendidikan.

Online

http://file.upi.edu/direktori/kdtasikmalaya/dindin_abdul_muiz_lidinillah_tasikmalaya)197901132005011003/132313548\%20\%20dindin\%20abdul\%20muiz\%2 0lidinillah/developmentally\%20appropriate\%20practice\%20(ap.pdf [ 31 oktober 2014 ]

http://www.academia.edu/7663298/Modifikasi_Pembelajaran_penjasorkes

Berbasis_PAIKEM_Pada_Standar_Proses.

http://hanafiunespenjaskes.blogspot.com/2012/03/teori-dan-tujuan-penjaskes.html. 